\title{
THE EFFECT OF PLANT GROWTH PROMOTING BACTERIA ON TRANSPLANTS GROWTH AND LETTUCE YIELD IN ORGANIC PRODUCTION
}

\author{
Magdalena SZCZECH*, Anna SZAFIROWSKA, Waldemar KOWALCZYK, \\ Justyna SZWEJDA-GRZYBOWSKA, Agnieszka WŁODAREK, Robert MACIOROWSKI \\ Research Institute of Horticulture \\ Konstytucji 3 Maja 1/3 str., 96-100 Skierniewice, Poland
}

Received: June 2016; Accepted: November 2016

\begin{abstract}
Application of beneficial bacterial strain B125 (Enterobacter sp.) and strain PZ9 (Bacillus sp.) in lettuce transplants production significantly enhanced seed germination and plant biomass. The best effect was obtained when the mixture of B125 and PZ9 was used. Combined application of these bacteria significantly increased transplants biomass, which was about $45 \%$ higher than that in the control. However, after planting these transplants in organic field, generally, there were no differences in yield and nutrient content in plants treated and not treated with the bacteria, except for nitrogen and vitamin $\mathrm{C}$. The lettuce grown from transplants treated with bacterial mixture B125 + PZ9 contained significantly higher nitrogen than plants from other treatments. Opposite to nitrogen, bacterial applications decreased the amount of vitamin $\mathrm{C}$. The growth and organic lettuce composition was affected by planting time. The yield was higher in spring, but the concentration of nutrients in these plants was lower than that in plants harvested in autumn. Climatic and light conditions in the late season were the reasons for increased dry matter content, minerals, phenolic compounds, and vitamin $\mathrm{C}$, as well as high concentration of nitrates.
\end{abstract}

Key words: organic lettuce, transplants bacterization, yield quality

\section{INTRODUCTION}

Organic farming is expanding worldwide and supported by regional and national governments. However, this system is facing many problems, mostly related to nutrient supply limitation and disease control management. Plant growth in organic system greatly depends on organic matter inputs and the functions performed by soil microorganisms ( $\mathrm{Tu}$ et al. 2006). The microorganisms are responsible for releasing nutrients from organic matter and can positively influence the plant growth. Especially, plantgrowth-promoting bacteria (PGPB) may be beneficial to plants because of the increase in seed germination rate, plant growth, tolerance to abiotic stress, enhancing nutrients availability, producing plant hormones, disease suppression, and plant-mediated induced resistance (Compant et al. 2010; Figueiredo et al. 2010). The use of PGPB as inoculants offers an attractive way to improve efficacy or replace chemical fertilizers and pesticides, especially in organic farming, where chemicals are not accepted. According to Mahdi et al. (2010), biofertilisers are essential components of organic farming and play a vital role in maintaining long-term soil fertility and sustainability by fixing atmospheric dinitrogen, mobilizing fixed macro- and micronutrients, or converting insoluble $\mathrm{P}$ in the soil into forms available to plants. There are examples of commercialized bacterial inoculants (Figueiredo et al. 2010; Bhattacharyya $\&$ Jha 2012). However, the linkages between soil microbes and nutrients availability or disease suppression in organically managed soils are still not well understood, and farmers should be aware of the specific needs of these microorganisms and their limitations. There is need for implementation of the 
knowledge on the effectiveness of microbial inoculants in field conditions.

Production of vigorous transplants, which would be tolerant to changeable conditions even a few weeks after transferring to the field, is very important in organic production, where plant support with agrochemicals is limited. Therefore, the aim of this work was to find effective bacterial inoculant for lettuce transplants production and to study whether the seedling growth promotion will expand as a long-term effect in the field, in organic farming system, affecting yield and nutrient content.

\section{MATERIALS AND METHODS}

Bacterial strains B125 (Enterobacter sp.) and PZ9 (Bacillus sp.) were taken from the collection of Laboratory of Microbiology in the Research Institute of Horticulture in Skierniewice, Poland. Strain 125 was isolated from vermicompost and PZ9 from the rhizosphere of tomato plant. The bacteria were screened for plant-growth-promoting traits. B125 was able to produce siderophores and indole-3-acetic acid (IAA). This strain intensively degraded cellulose. PZ9 produced siderophores and IAA and strongly solubilized phosphate. The strains were classified to a genus using biochemical and molecular methods. For biochemical classification, Gram reaction, anaerobic growth, fluorescent pigment, catalase test, and indole production were examined according to Schaad et al. (2001). Then, biochemical API 20E and API 50CHB tests (BioMérieux) were used. According to API 20E, strain B125 was identified as Enterobacter, and API 50CHB classified PZ9 as Bacillus. This preliminary identification was confirmed by molecular classification with polymerase chain reaction (PCR), using ERIC1f/ERIC2 starters, and based on the sequence of $16 \mathrm{~S}$ rDNA gene. The sequences were compared using BLASTn program (www.ncbi.nlm.nih.gov).

To prepare the inoculum, bacteria were grown in nutrient broth $(100 \mathrm{ml})$ on the rotary shaker for $48 \mathrm{~h}$ at $30^{\circ} \mathrm{C}$. After incubation, bacterial cultures were diluted with $0.85 \% \mathrm{NaCl}$ water solution to obtain the inoculum with the final cell density of about $10^{10} \mathrm{cfu} \mathrm{cm}^{-3}$.
Iceberg lettuce cv. 'Królowa Lata' (PNOS Ożarów, Poland) was sown in planting trays (56 pots, each of volume $100 \mathrm{~cm}^{3}$ ) filled with non-sterile growing medium. Bacteria were applied by drenching of the medium in a dose of $10 \mathrm{~cm}^{3}$ of bacterial suspension per one cell. The suspensions of single strains B125 and PZ9 or their mixture $(1: 1 \mathrm{v} / \mathrm{v})$ were used for inoculation. Control was treated with water. Bacterial inoculation was repeated after two weeks. Each treatment included four trays arranged in a randomized blocks. Lettuce was grown in the greenhouse at ambient temperature for four weeks. The number of plants in each tray was counted to estimate the germination rate, and randomly chosen plants (10 items from each treatment) were harvested by cutting the stems at the soil level. The plants were then weighted to measure their fresh weight. There were five cycles of transplants production: two during spring 2009 and 2011 and three during autumn in the years 2009-2011.

Field experiments were carried out in the years 2009-2011 at the experimental, certificated organic farming field of Research Institute of Horticulture in Skierniewice. Each year, the lettuce was grown during two cropping seasons: spring and autumn. Compost $\left(20 \mathrm{t} \cdot \mathrm{ha}^{-1}\right)$ and green manures (mulched mustards) were added to the soil (pseudopodzols) before planting. Chemical properties of the soil

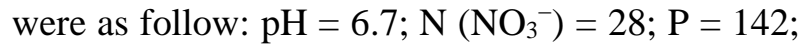
$\mathrm{K}=99 ; \mathrm{Mg}=89 ; \mathrm{Ca}=871\left(\mathrm{mg} \cdot \mathrm{dm}^{-3}\right)$. The experimental field was divided into plots with an area of $3.4 \mathrm{~m}^{2}$ with 14 plants per plot. Lettuce transplants used for field experiments were obtained from the greenhouse production described earlier. The transplants were inoculated with PGPB during their growth in planting trays, and they were not bacterized additionally in the field. The experimental objects were control, not bacterized transplants; transplants bacterized with B125; transplants bacterized with PZ9; and transplants bacterized with B125 + PZ9. Each treatment included four replications/plots arranged in randomized complete block. When plants reached their commercial size, they were harvested by cutting the stems at the soil level. The yield of lettuce was calculated for square meter. Four randomized lettuce heads were collected from 
each treatment for chemical and biochemical analyses of plant material.

For chemical analysis, the lettuce was dried at $65^{\circ} \mathrm{C}$, homogenized with mill, and mineralized in a mixture of concentrated acids in a microwave oven (Walinga et al. 1995). N content in plant samples was analyzed using the Kjeldahl method. Sequential plasma spectrometer model Optima 2000 DV (Perkin-Elmer) was used to measure the macronutrients content (P, K, Mg, Ca) (Boss \& Fredeen 1999). The elements were measured at a wavelength characteristic of the analyte. Nitrates $(\mathrm{V})$ were determined with the use of flow-injection system after homogenization of plant material in aqueous solution (Mikuška \& Večeřa 2003). Dry matter content was measured after drying of plant material at $105^{\circ} \mathrm{C}$ to a constant weight. Total sugars were estimated by the common Luff-Schoorl's method and ascorbic acid by Tillman's method (according to PN-90A-75101/07). The results were expressed on a fresh weight basis. The polyphenols content was determined by spectrophotometric method at $725 \mathrm{~nm}$ with the use of Folin-Ciocalteu reagent (Ragazzi \& Veronese 1973) with catechin as a standard. The values were expressed as mg catechin equivalents per $\mathrm{kg}$ of fresh weight $\left(\mathrm{mg} \cdot \mathrm{kg}^{-1}\right)$.

Data were analyzed by means of the linear mixed model with variant, season as the fixed effects and year, block as the random effects. The Box-Cox transformation for infestation data was used before analysis. Means were separated with the Duncan multiple comparison procedure at significance level of $p=0.05$. All calculations were done with the statistical software STATISTICA 10.0 (StatSoft, Inc. 2013).

\section{RESULTS AND DISCUSSION}

Production of uniform and vigorous transplants is very important in organic farming, because such plants can better establish in less favorable conditions after planting in field. The application of beneficial bacteria may be a way to improve the growth of young plants. In this work, we used a combination of pot and field investigations to study bacterial impact on lettuce transplants growth and then on the yield and nutrient uptake in organic production. For the study, two bacterial strains B125 and PZ9 were chosen. In previous experiments, these bacteria promoted growth of vegetable plants (tomato, cucumber), even in growing media infested with pathogens (Szczech \& Dyki 2007; Szczech \& Dyśko 2008; Szczech et al. 2009). In presented experiments, application of the bacteria enhanced germination of lettuce seeds (Table 1).

Table 1. The effect of bacterial inoculation on lettuce germination and transplants growth. Data represent means \pm SE of the results obtained in five consecutive experiments conducted in the years 2009-2011

\begin{tabular}{lcc}
\hline $\begin{array}{c}\text { Inoculation } \\
\text { treatment }\end{array}$ & $\begin{array}{c}\text { Seed } \\
\text { germination } \\
(\%)\end{array}$ & $\begin{array}{c}\text { Fresh mass } \\
\text { of transplants } \\
(\mathrm{g})\end{array}$ \\
\hline Control & $62.5 \pm 1.72 \mathrm{~b}$ & $4.64 \pm 0.27 \mathrm{c}$ \\
B125 & $69.6 \pm 1.72 \mathrm{ab}$ & $5.11 \pm 0.21 \mathrm{~b}$ \\
PZ9 & $70.0 \pm 1.84 \mathrm{ab}$ & $4.43 \pm 0.44 \mathrm{c}$ \\
$\mathrm{B} 125+$ PZ9 & $76.6 \pm 2.49 \mathrm{a}$ & $6.71 \pm 0.31 \mathrm{a}$ \\
\hline
\end{tabular}

Values in a column followed by the same letter are not significantly different according to the Duncan multiple range test at $\mathrm{p}=0.05$.

Single strains had not stabile effect, and they only slightly influenced germination and transplants growth. The best effect was obtained when the mixture of both bacteria B125 and PZ9 was used. Combined application of these bacteria significantly increased seed germination and transplants biomass, which was about $45 \%$ higher than in control. The beneficial effect of PGPB for plants was described in many papers (Glick 1995; Lucy et al. 2004; Ahemad \& Kibret 2014). Inoculation of crops by PGPB may result in the improvement of early plant growth: enhancement of seedling germination, stand health, shoot and root weight of seedlings, as well as further plant development and yield (Saharan \& Nehra 2011). Mangmang et al. (2015) reported positive effect of Azospirillum brasilense on seedling growth of lettuce, tomato, and cucumber. The growth of roots of lettuce seedlings was also significantly promoted by the inoculation of the seeds with Rhizobium leguminosarum (Noel et al. 1996). In our study, mixture of two bacterial strains gave the most stable effect of plant growth promotion, and this result confirms the findings that combination of several 
microorganisms may be more effective in agricultural practice than single strains (Szczech 2008).

Five consecutive experiments proved that application of bacterial strains B125 and PZ9 is a promising way to improve lettuce germination and to produce strong, uniform seedlings. The bacteria accelerated growth of young plants, thus such treatment may reduce time necessary for transplants production. The next goal was to determine if the early responses in plant growth after the application of these bacteria would persist when seedlings had been transplanted to organic field. However, three years of field experiments have shown that even serious promotion of plant growth by PGPB during transplants production had no effect on the yield of lettuce. It was only found that application of the mixture of B125 + PZ9 had a prolonged influence on nitrogen uptake in the field. The lettuce heads grown from transplants treated with these bacteria contained significantly higher nitrogen than plants from other treatments (Fig. 1). It could be also a reason for lower concentration of vitamin $\mathrm{C}$ in treated plants than that in not bacterized lettuce (Fig. 2). According to Worthington (2001) and Herencia et al. (2011), when plants present high nitrogen content, the production of vitamin $\mathrm{C}$ is reduced. High nitrogen causes an increase in protein production and decrease in carbohydrates, which are the base for the synthesis of vitamin $\mathrm{C}$. The concentrations

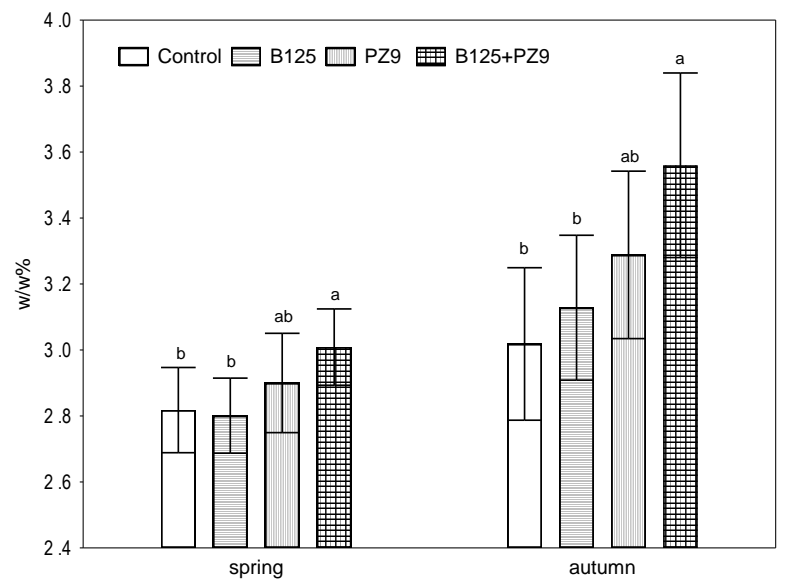

Fig. 1. Effect of inoculation treatments and vegetation season on total nitrogen content in lettuce head (means \pm $\mathrm{SE})$. Bars followed by the same letter for each season separately are not significantly different at $\mathrm{p}=0.05$ according to the Duncan multiple range test of other macronutrients in lettuce, including nitrates $(\mathrm{V})$, were not affected by inoculation treatments. Dry matter, sugars, and polyphenols were not affected as well. The results have shown that beneficial effect of bacteria obtained during early stages of plants growth generally diminished in field conditions. The possible reason was that the application of bacterial inoculum during transplants production was not sufficient to support bigger plants in field.

In planting trays, in limited volume of growing medium, the bacteria were concentrated and it was enough to stimulate plants. In field, introduced bacteria might face strong competition with indigenous microorganisms, especially in organically cultivated soil, where microbial biodiversity is higher and nutrient availability is lower than that in conventionally fertilized soils (Srivastva et al. 2007; Moeskops et al. 2010). Similar results were obtained by Russo and Perkins-Veazie (2010) while studying the effectiveness of bacteria and arbuscular mycorrhizal fungi applied in the production of bell pepper transplants, which were then cultivated in an organic system. The yield obtained from control and treated pepper was comparable, despite significant transplants stimulation by used microorganisms. However, there are also reports that various bacteria have increased lettuce growth in pot and field experiments (Sottero et al. 2006; Chamangasht et al. 2012).

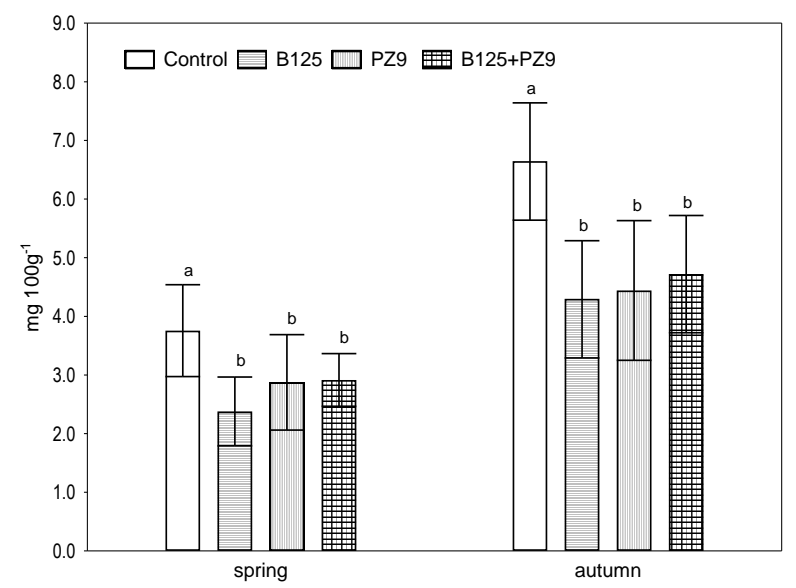

Fig. 2. Effect of the season and inoculation with PGPB on vitamin $C$ content in lettuce heads (means $\pm S E$ ). Bars followed by the same letter for each season separately are not significantly different at $\mathrm{p}=0.05$ according to the Duncan multiple range test 
Perhaps consecutive applications of active microorganisms during growing season would improve their effectiveness. Kowalska and Remlein-Starosta (2012) reported that multiple treatments of potato with bio-preparate containing fungus Trichoderma asperellum significantly inhibited potato late blight and increased the yield in organic production.

In this work, the factor affecting growth and lettuce composition was time of planting. The yield obtained in spring was about $25 \%$ higher than that in autumn (Table 2). Higher lettuce production in spring cultivation was also reported by Pavlou et al. (2007) and Rolbiecki et al. (2013). The main reason for seasonal differences was weather. In spring, rainfalls and daily temperatures were higher than those in autumn. Kosma et al. (2013) described that higher fresh biomass may also be enhanced in relation to light exposure. In opposite, decreased growth rate and reduced plant biomass in autumn resulted in enhanced dry weight of lettuce and accumulation of nutrients (Table 2). According to Herencia et al. (2011) and Kleiber et al. (2013), in less favorable conditions during autumn, synthesis of N-poor molecules (e.g., polyphenols, cellulose, starch) may increase dry matter content.

Table 2. The differences in yield, dry matter content, and chemical properties of lettuce, according to the time of cultivation (the data are presented as mean values $\pm \mathrm{SE}$ calculated for all treatments in the seasons spring and autumn)

\begin{tabular}{lcc}
\hline \multicolumn{1}{c}{ Trait } & Spring & Autumn \\
\hline Yield $\left(\mathrm{kg} \mathrm{m}^{-2}\right)$ & $2.32 \pm 0.07 \mathrm{a}$ & $1.75 \pm 0.11 \mathrm{~b}$ \\
Dry weight $(\%)$ & $4.31 \pm 0.06 \mathrm{~b}$ & $7.67 \pm 0.42 \mathrm{a}$ \\
Total sugars $(\%)$ & $2.05 \pm 0.05 \mathrm{~b}$ & $2.49 \pm 0.03 \mathrm{a}$ \\
Polyphenols & $21.5 \pm 0.63 \mathrm{~b}$ & $66.4 \pm 7.42 \mathrm{a}$ \\
$\left({\left.\mathrm{mg} 100 \mathrm{~g}^{-1}\right)}\right.$ & $672 \pm 50 \mathrm{~b}$ & $1.626 \pm 152 \mathrm{a}$ \\
Nitrates $(\mathrm{V})$ & $3.410 \pm 150 \mathrm{~b}$ & $4.420 \pm 198 \mathrm{a}$ \\
$\mathrm{P}\left(\mathrm{mg} \mathrm{kg}^{-1}\right)$ & $42.866 \pm 966 \mathrm{~b}$ & $44.217 \pm 2.994 \mathrm{a}$ \\
$\mathrm{K}\left(\mathrm{mg} \mathrm{kg}^{-1}\right)$ & $1.906 \pm 39 \mathrm{~b}$ & $2.440 \pm 87 \mathrm{a}$ \\
$\mathrm{Mg}\left(\mathrm{mg} \mathrm{kg}^{-1}\right)$ & $4.696 \pm 116 \mathrm{~b}$ & $9.528 \pm 383 \mathrm{a}$ \\
$\mathrm{Ca}\left(\mathrm{mg} \mathrm{kg}^{-1}\right)$ & & \\
\hline
\end{tabular}

Values in a row followed by the same letter are not significantly different according to the Duncan multiple range test at $\mathrm{p}=0.05$.
A significant correlation between higher dry matter content and increased amount of macro- and micronutrients in lettuce was observed by Fontanetti et al. (2001) and Koudela and Petř́ková (2008). In our study, the strongest accumulation in lettuce leaves was obtained for polyphenols, calcium, and nitrates (Table 2). Nitrate content in plants is mainly affected by nitrogen fertilization and light intensity (Pavlou et al. 2007). It also varies with plant species and cultivar, and leafy green vegetables are the most sensitive to nitrate accumulation. In Poland, during autumn, light intensity and number of sunny days is limited. Under low-light conditions, lettuce may accumulate relatively large amounts of $\mathrm{NO}^{3-}$ as a result of an excess uptake over reduction (Demšar et al. 2004). The seasonal differences in nitrates content for lettuce were observed in other experiments (Muramoto 1999; Herencia et al. 2011). In our study, organic lettuce harvested in October contained over twofold more nitrates than in plants collected in July. However, there is an opinion that organically grown vegetables have lower nitrate content than conventionally grown crops (Stopes et al. 1989; Muramoto 1999; Herencia et al. 2011).

\section{CONCLUSIONS}

Application of the mixture of bacterial strains PZ9 and B125 at the early stage of lettuce growth increased young plants biomass for $45 \%$ compared to control. It suggests that this mixture of bacteria may be successfully used for transplants production. However, this strong beneficial effect was not prolonged during further growth of the lettuce in organic field. Finally, the yield was not affected by the used bacteria. The only trace of bacterial activity was higher nitrogen uptake in treated plants. Probably, the application of active bacteria only during transplants growth may not be sufficient to obtain better yield, and the treatments should be continued during vegetation. Moreover, three-year experiment with lettuce grown in organic system has shown that cultivation of these plants in late season of vegetation (August-October) resulted in low yield quality. The lettuce heads were small and with high nitrates concentration. It is possible that lower light intensity and temperatures, typical for 
this time, affected negatively growth and plants composition. Therefore, there is a question about the reasonability of lettuce cultivation in the late season of vegetation in Polish climatic condition.

\section{REFERENCES}

Ahemad M., Kibret M. 2014. Mechanisms and applications of plant growth promoting rhizobacteria: current perspective. Journal of King Saud University - Science 26: 1-20. DOI: 10.1016/j.jksus.2013.05.001.

Bhattacharyya P.N., Jha D.K. 2012. Plant growth-promoting rhizobacteria (PGPR): emergence in agriculture. World Journal of Microbiology and Biotechnology 28: 1327-1350. DOI: 10.1007/s11274011-0979-9.

Boss C.H., Fredeen K.J. 1999. Concepts, Instrumentation, and Techniques in Inductively Coupled Plasma Optical Emission Spectrometry. Perkin Elmer.

Chamangasht S., Ardakani M.R., Khavazi K., Abbaszadeh B., Mafakheri S. 2012. Improving lettuce (Lactuca sativa L.) growth and yield by the application of biofertilizers. Annals of Biological Research 3(4):1876-1879.

Compant S., Clément C., Sessitsch A. 2010. Plant growth-promoting bacteria in the rhizo- and endosphere of plants: Their role, colonization, mechanisms involved and prospects for utilization. Soil Biology and Biochemistry 42: 669-678. DOI: 10.1016/j.soilbio.2009.11.024.

Demšar J., Osvald J., Vodnik D. 2004. The effect of lightdependent application of nitrate on the growth of aeroponically grown lettuce (Lactuca sativa $\mathrm{L}$.). Journal of the American Society for Horticultural Science 129(4): 570-575.

Figueiredo M.V.B., Seldin L., De Araujo F.F., De Mariano R.L.R. 2010. Plant growth promoting rhizobacteria: fundamentals and applications. In: Maheshwari D.K. (Ed.), Plant Growth and Health Promoting Bacteria. Microbiology Monographs 18: 21-43.

Fontanetti M.V., de Lima M.S., Morgor A.F., Goto R. 2001. Production of iceberg lettuce using mulches. Scientia Agricola 58(4): 737-740. DOI: 10.1590/S0103-90162001000400014.

Glick B.R. 1995. The enhancement of plant growth by free-living bacteria. Canadian Journal of Microbiology 41: 109-117.

Herencia J.F., García-Galavís P.A., Ruiz Dorado J.A., Maqueda C. 2011. Comparison of nutritional quality of the crops grown in an organic and conventional fertilized soil. Scientia Horticulturae 129: 882-888. DOI: 10.1016/j.scienta.2011.04.008.

Kleiber T., Starzyk J., Bosiacki M. 2013. Effect of nutrient solution, effective microorganisms (EM-A), and assimilation illumination of plants on the induction of the growth of lettuce (Lactuca sativa $\mathrm{L}$.) in hydroponic cultivation. Acta Agrobotanica 66(1): 27-38. DOI: 10.5586/aa.2013.004.

Kosma C., Triantafyllidis V., Papasavvas A., Salahas G., Patakas A. 2013. Yield and nutritional quality of greenhouse lettuce as affected by shading and cultivation season. Emirates Journal of Food and Agriculture 25(12): 974-979. DOI: 10.9755/ejfa.v25i12.16738.

Koudela M., Petř́íková K. 2008. Nutrients content and yield in selected cultivars of leaf lettuce (Lactuca sativa L. var. crispa). Horticultural Science (Prague) 35: 99-106.

Kowalska J., Remlein-Starosta D. 2012. Influence of frequency and way of application of bio-preparate (Trichoderma asperellum) on limitation of potato late blight and yield of organic potato. Progress in Plant Protection/Postępy w Ochronie Roślin 52(2): 347-350. [in Polish with English abstract]

Lucy M., Reed E., Glick B.R. 2004. Applications of free living plant growth-promoting rhizobacteria. Antonie van Leeuwenhoek 86: 1-25. DOI: 10.1023/B:ANTO.0000024903.10757.6e.

Mahdi S.S., Hassan G.I., Samoon S.A., Rather H.A., Dar S.A., Zehra B. 2010. Bio-fertilizers in organic agriculture. Journal of Phytology 2(10): 42-54.

Mangmang J.S., Deaker R., Rogers G. 2015. Early seedling growth response of lettuce, tomato and cucumber to Azospirillum brasilense inoculated by soaking and drenching. Horticultural Science (Prague) 42: 37-46. DOI: 10.17221/159/2014-HORTSCI.

Mikuška P., Večeřa Z. 2003. Simultaneous determination of nitrite and nitrate in water by chemiluminescent flow-injection analysis. Analytica Chimica Acta 495: 225-232. DOI: 10.1016/j.aca.2003.08.013.

Moeskops B., Sukristiyonubowo, Buchan D., Sleutel S., Herawaty L., Husen E. et al. 2010. Soil microbial communities and activities under intensive organic and conventional vegetable farming in West Java, Indonesia. Applied Soil Ecology 45: 112-120. DOI: 10.1016/j.apsoil.2010.03.005.

Muramoto J. 1999. Comparison of nitrate content in leafy vegetables from organic and conventional farms in California. Center of Agroecology and Sustainable Food Systems, University of California, Santa Cruz, $64 \mathrm{p}$. 
Noel T.C., Sheng C., Yost C.K., Pharis R.P., Hynes M.F. 1996. Rhizobium leguminosarum as a plant growthpromoting rhizobacterium: direct growth promotion of canola and lettuce. Canadian Journal of Microbiology 42(3): 279-283. DOI: 10.1139/m96-040.

Pavlou G.C., Ehaliotis C.D., Kavvadias V.A. 2007. Effect of organic and inorganic fertilizers applied during successive crop seasons on growth and nitrate accumulation in lettuce. Scientia Horticulturae 111: 319-325. DOI: 10.1016/j.scienta.2006.11.003.

Ragazzi E., Veronese G. 1973. Quantitative analysis of phenolic compounds after thin-layer chromatographic separation. Journal of Chromatography A 77: 369-375. DOI: 10.1016/S0021-9673(00)92204-0.

Rolbiecki S., Rolbiecki R., Piszczek P., Knapowski T., Ptach W., Sositko S. 2013. Comparison of yields of the three romaine lettuce cultivars in spring and autumn cultivation on the very light soil under fertigation of nitrogen by drip system. Infrastructure and Ecology of Rural Areas 3/IV: 325-335. [in Polish with English abstract]

Russo V.M., Perkins-Veazie P. 2010. Yield and nutrient content of bell pepper pods from plants developed from seedlings inoculated, or not, with microorganisms. HortScience 45(3): 352-358.

Saharan B.S., Nehra V. 2011. Plant growth promoting rhizobacteria: a critical review. Life Sciences and Medicine Research 21: 1-30.

Schaad N.W., Jones J.B., Chun W. 2001. Laboratory guide for identification of plant pathogenic bacteria. APS Press, 398 p.

Sottero A.N., Freitas S.S., Melo A.M.T., Trani P.E. 2006. Rhizobacteria and lettuce: root colonization, plant growth promotion and biological control. Revista Brasileira de Ciência do Solo 30(2): 225-234. DOI: 10.1590/S0100-06832006000200004. [in Portuguese with English abstract]

Srivastva R., Roseti D., Sharma A.K. 2007. The evaluation of microbial diversity in vegetable based crop- ping system under organic farming practices. Applied Soil Ecology 36: 116-123. DOI: 10.1016/j.apsoil.2007.01.008.

Stopes C., Woodward L., Forde G., Vogtmann H. 1989. Effects of composted FYM and a compound fertiliser on yield and nitrate accumulation in three summer lettuce cultivars grown in an organic system. Agriculture, Ecosystems and Environment 27(1-4): 555-560. DOI: 10.1016/0167-8809(89)90116-3.

Szczech M. 2008. Mixtures of microorganisms in biocontrol. In: Kim Myung-Bo (Ed.), Progress in environmental microbiology. Nova Science Publishers, pp. 69-110.

Szczech M., Dyki B. 2007. Combination of microbial biocontrol agents to control rhizoctonia damping-off and fusarium wilt of tomato. IOBC/WPRS Bulletin 30(6): 415-418.

Szczech M., Dyśko J. 2008. The possibility to use selected mixtures of PGPR bacteria in tomato cultivation. Vegetable Crops Research Bulletin 68: $47-$ 56. DOI: 10.2478/v10032-008-0004-5.

Szczech M., Kowalska B., Dyki B., Horbowicz M., Kowalczyk W. 2009. Microbial mixtures enhancing plant resistance to pathogen stress. IOBC/WPRS Bulletin 43: 89-94.

Tu C., Louws F.J., Creamer N.G., Mueller J.P., Brownie C., Fager K. et al. 2006. Responses of soil microbial biomass and $\mathrm{N}$ availability to transition strategies from conventional to organic farming systems. Agriculture, Ecosystems and Environment 113: 206215. DOI: 10.1016/j.agee.2005.09.013.

Walinga I., van der Lee J.J., Houba V.J.G., van Vark W., Novozamsky I. 1995. Plant analysis manual. Kluwer Academic Publisher. DOI: 10.1007/97894-011-0203-2.

Worthington V. 2001. Nutritional quality of organic versus conventional fruits, vegetables, and grains. Journal of Alternative and Complementary Medicine 7: 161-173. DOI: 10.1089/107555301750164244. 